\title{
SUPPLEMENTATION OF COFFEE HUSK FERMENTED WITH Pleurotus ostreatus: EFFECT ON PERFORMANCE AND BLOOD PROFILE OF GASTROINTESTINAL NEMATODES INFECTED GOAT
}

\author{
I. Badarina, H. D. Putranto and E. Sulistyowati \\ Faculty of Agriculture, Bengkulu University, \\ Jalan W.R. Supratman Kandang Limun, Bengkulu - Indonesia \\ Corresponding E-mail:ibadarina@yahoo.com
}

Received September 17, 2015; Accepted November 28, 2015

\begin{abstract}
ABSTRAK
Penelitian ini bertujuan untuk mengevaluasi potensi kulit buah kopi yang telah difermentasi dengan Pleurotus ostreatus sebagai suplemen obat cacing alami dengan mengukur performa dan profil darah kambing yang menderita infeksi nematoda. Sebanyak 18 ekor kambing Kacang jantan berumur seragam ( \pm 10 bulan) dengan rata-rata berat badan $9,23 \pm 1,71 \mathrm{~kg}$ dialokasikan ke dalam tiga perlakuan dalam rancangan acak lengkap yaitu T0 (grup yang tidak diberi obat anthelmintik dan tidak disuplementasi kulit buah kopi fermentasi), T1 (grup yang tidak diberi obat anthelmintik, tetapi mendapat suplementasi kulit buah kopi fermentasi) dan T2 (grup yang diberi obat anthelmintik, tetapi tidak disuplementasi kulit buah kopi fermentasi). Ransum basal terdiri dari 60\% rumput alam dan 40\%konsentrat. Kulit buah kopi fermentasi ditambahkan sebanyak 6\% dari kebutuhan bahan kering ransum. Hasil penelitian menunjukkan perlakuan tidak memberikan pengaruh yang nyata terhadap konsumsi bahan kering, pertambahan berat badan harian, nilai Packed Cell Volume (PCV) dan jumlah eosinophil $(\mathrm{P}>0,05)$. Suplementasi kulit buah kopi fermentasi (T1) meningkatkan nilai Hemoglobin ( $\mathrm{Hb})$ dan Red Blood Cell (RBC) $(\mathrm{P}<0,05)$. Tidak terdapat perbedaan yang nyata antara $\mathrm{T} 1$ dan $\mathrm{T} 2$ terhadap nilai $\mathrm{Hb}$ dan $\mathrm{RBC}$. Tidak terdapat infeksi nematoda setelah mendapat perlakuan $\mathrm{T} 1$ dan $\mathrm{T} 2$ yang ditunjukkan dengan nilai Egg Count nol sementara pada T0 masih menderita infeksi nematoda. Hasil penelitian ini memberikan indikasi bahwa kulit buah kopi yang telah difermentasi oleh P.ostreatus dapat digunakan sebagai suplemen anticacing alami dengan perbaikan terhadap nilai $\mathrm{Hb}$, nilai $\mathrm{RBC}$, jumlah telur dalam feses dan pertambahan berat badan harian.
\end{abstract}

Kata Kunci : kulit buah kopi fermentasi, pakan suplemen anticacing, performa, profil darah, kambing

\begin{abstract}
The aim of this study was to investigate the potency of coffee husk fermented with P.ostreatus as a natural anthelmintic supplement by measuring the performance and blood profile of goat suffered gastrointestinal nematodes infection. Eighteen local male goats of Kacang goat with body weight of $9.23 \pm 1.71 \mathrm{~kg}$ and aged at \pm 10 months were arranged into three treatments in completely randomized design. The treatments were T0 (group without chemical anthelmintic treatment and no supplementation of fermented coffee husk), T1 (without chemical anthelmintic treatment, but supplied with fermented coffee husk) and T2 (group with chemical anthelmintic and no supplementation of fermented coffee husk). All goats were offered a basal diet in the ratio of $60 \%$ natural grasses along with $40 \%$ concentrate. Fermented coffee husk was added in the diet as much as $6 \%$ from the dry matter need. The result showed that there were no significant effect to dry matter intake, daily weight gain, PCV value and eosinophil counts $(\mathrm{P}>0.05)$. The supplementation of fermented coffee husk (T1) enhanced $\mathrm{Hb}$ and red blood cell $(\mathrm{RBC})$ value $(\mathrm{P}<0.05)$ while no significant difference to $\mathrm{T} 2$. There were no nematodes
\end{abstract}


infection in T1 and T2 with the eggs count were zero while the animals in T0 were still infected. This result indicated that fermented coffee husk can be used as a promising natural anthelmintic supplement with the improvement of $\mathrm{Hb}$ value, $\mathrm{RBC}$, egg counts and daily weight gain.

Keywords: fermented coffee husk, anthelmintic feed suplement, performance, blood profile, goat

\section{INTRODUCTION}

Gastrointestinal (GI) nematodes infection constitutes a major health problem for humans and animals in many parts of the world. The consequence of nematodes infection is adverse effects on the productivity of animal such as decrease the appetite, more susceptible to high prevalence and frequent outbreaks of infectious diseases (Pathak and Pal, 2008).

The customary mode of control of these GI nematodes has been based on the repeated use of chemical anthelmintics. However, drug resistance has become an important issue in small ruminant husbandry. The intensive use of drugs in the livestock industry has led to widespread resistance to all current anthelmintics (Wolstenholme et al., 2004; Sissouma et al., 2011).

Alternative environment friendly sustainable novel strategies are required, which could reduce the exclusive reliance on anthelmintic treatment. Plants have been used from ancient times to cure diseases of man and animals. There are many plants which have been reported in the literature for their anthelmintic importance.

Mushrooms have been also used as food supplement from times because of their medicinal properties. One of the mushrooms is P.ostreatus posseses a number of active compounds help in health-enhancers, potentiating against diseases, biological respon modifiers (Wong et al., 2011; Patel et al., 2012). There were the increasing limphocyte and the decreasing of eosinophyl counts from the PE goat supplied with solid subtrate of $P$. Ostreatus made from coffee husk (Badarina et al., 2014). This indicated that fermented coffee husk could improve immunity which enhanced the onset of parasite rejection.

The bioactive substance responsibles for biological action is $\beta$-glucan, a part of polysaccharides that form an integral part of fungal cell wall (Chen and Seviour, 2007). The application of fermented coffee husk against internal parasites could be due to its metabolic secondary substances such as saponin, tannin, alkaloid, flavonoid, glicosides and triterpenoid (Badarina et al., 2013). These substances were found in chemical anthelmintics drugs and botanical anthelmintics (Zafar et al., 2004; Suharti et al., 2010 ).

The aim of this study was to investigate the potency of coffee husk fermented with P.ostreatus as a natural anthelmintic supplement by measuring the performance and blood profile of goat suffered gastrointestinal nematodes infection.

\section{MATERIALS AND METHODS}

\section{Coffee Husk Cultivation with Pleurotus ostreatus}

Coffee husks were sun dried until its moisture content range was $10 \%-15 \%$. The cultivation method and the composition of solid substrate were conducted according to Herliyana et al. (2008) with slight modification. The substrate consisted of $82.5 \%$ of coffee husks, $15 \%$ rice bran, $1.5 \%$ gypsums, and $1.0 \% \mathrm{CaCO}_{3}$. The clean water was added into the substrate as much as $65 \%-70 \%(\mathrm{v} / \mathrm{w})$. All the components were composted for $24 \mathrm{~h}$ and then was placed into polypropylene bags as much as $400 \mathrm{~g}$ per bag. The bag logs were sterilized on $121^{\circ} \mathrm{C}$ for $30 \mathrm{~min}$. After cooling, each bag was inoculated aseptically with P.ostreatus grain spawn and incubated in an incubating room at $23-24^{\circ} \mathrm{C}$ and approximately $80 \%$ relative humidity. Each spawned bag was closed with a small sterile cotton plug inserted in the middle of its opening. All bags were placed in incubating room and after $60 \mathrm{~d}$ the substrates were fully colonized and the primordial started to appear. The fully colonized substrates were solar dried and ready to use as feed. The nutrient content of coffee husk substrate is presented in Table 1.

\section{Animals and Treatments}

Eighteen local male goats named Kacang goat were used in this experiment. The mean of goat body weights were $9.3 \pm 1.71 \mathrm{~kg}$ with similar age ( \pm 10 months). All goats were selected from the traditional farmer and suffered gastro intestinal nematodes (GINs) based on fecal egg count (FECs). The FECs were made using the modified McMaster technique (MAFF, 1986). All experimental goats were arranged in a completely 
randomized design.

All the goats were allocated in three different groups i.e. T0 (no chemical anthelmintic treatment and no supplementation of fermented coffee husk), T1 (no chemical anthelmintic treatment, animals supplied with fermented coffee husk) and T2 (group with anthelmintic treatment and no supplementation of fermented coffee husk). All goats were housed individually with facilities for individual feeding.

All goats were offered a basal diet in the ratio of $60 \%$ natural grasses and $40 \%$ concentrate mixture. The concentrate diet composed mainly of cassava waste, coconut meal, soybean wastes meal, rice bran and crude palm oil. The formulation and chemical analysis of concentrate was shown in the Table 2. Goats were fed twice daily in adequate amounts to ensure $3.5 \%$ dry matter intake of body weight at the day. The diet was arranged to fullfill the nutrient for goat with crude protein $11-12 \%$ and TDN $60 \%$ (Kearl, 1982). Fermented coffee husk was added in the diet of treatment (T1) as much as $6 \%$ of dry matter requirement (Badarina et al., 2014).

\section{Measurements of Feed Intake, Weight Gain and Blood Profile}

Feed intake: Voluntary feed intake (VFI) for each animal was recorded individually on daily basis. Feed intake was the difference between amount offered and amount left. Dry matter intake (DMI) was estimated from VFI x percentage of dry matter (DM). The weight gain evaluated by the difference between the weight after and before treatment. Feeding trial lasted for $45 \mathrm{~d}$.

Blood samples were obtained before morning feeding by venipuncture from jugular venous vein, it was collected into heparinized vacutainer. Blood samples were immediately placed into an ice-bath before processing. Blood samples were analyzed by standard methods (Jain, 1993). Packed cell volume (PCV) was determined by microhematocrit method, hemoglobin $(\mathrm{Hgb})$ concentration by spectrophotometric method, red blood cell (RBCs) and eosinophil counts by haemocytometer method. Blood profile were evaluated after and before treatment.

\section{Data Analysis}

All statistical analysis of the data obtained were performed to anova (Steel and Torrie, 2003). Means among treatments were compared by Duncan Multiple Range Test (DMRT). Statistical differences were expressed at $\mathrm{P}<0.05$.
Table 1. Nutrient Contents of Coffee Husk Substrate Fermented by Pleurotus ostreatus (dry matter)

\begin{tabular}{lc}
\hline \multicolumn{1}{c}{ Nutrient Component } & $\begin{array}{c}\text { Fermented } \\
\text { Coffee husk }\end{array}$ \\
\hline Organic matter (\%) & 86.60 \\
Crude protein (\%) & 12.14 \\
Crude fiber (\%) & 46.83 \\
Ether extract (\%) & 1.67 \\
NDF (\%) & 79.08 \\
ADF (\%) & 74.08 \\
Hemicelluloses (\%) & 5.32 \\
Celluloses (\%) & 24.79 \\
Lignin (\%) & 45.04 \\
Tannin (\%) & 0.18 \\
Caffein (\%) & 0.82 \\
$\beta$-glucan (\%w/w) & 4.25 \\
Ca (\%) & 1.28 \\
P (\%) & 0.08 \\
Fe (\%) & 0.11 \\
Zn (ppm) & 12.00 \\
\hline Badina
\end{tabular}

Badarina et al. (2013)

\section{RESULTS AND DISCUSSION}

\section{Dry Matter Intake and Weight Gain}

Table 3 shows the effect of treatments on feed intake and growth performance of goats. Intake of the dry matter was not significantly different $(\mathrm{P}>0.05)$ between treatments. The dry matter intake of all the treatment groups were higher than the feeding standard $0.35 \mathrm{~kg} / \mathrm{day}$ (Kearl, 1982). This condition meaned that the diet were palatable and the animals got the nutrients more than recommendation for standard weight gain 75 gram/day. Matanovic et al. (2007) stated that the animals with the good nutrient intake will have better ability to improve the immune system so decreasing the fecundity of excisting parasites.

In this research, the daily weight gain of the treatments were less than 75 gram. The highest daily gain was reached by T2 $(62.86 \pm 49.14 \mathrm{~g})$ and the lowest was T0 $(33.571 \pm 24.94 \mathrm{~g})$. This 
Table 2. Ingredients of Concentrate and Chemical Composition of Concentrate

\begin{tabular}{lc}
\hline \multicolumn{1}{c}{ Ingredient } & $\begin{array}{c}\text { Percentage of } \\
\text { DM }\end{array}$ \\
\hline Soybean wastes meal & 34.88 \\
Rice bran & 23.26 \\
Coconut wastes meal & 23.26 \\
Cassava wastes & 11.63 \\
Crude palm oil & 6.97 \\
Total & 100.00 \\
Dry matter(\%) & 85.05 \\
Ash (\%) & 10.38 \\
Crude protein (\%) & 15.33 \\
Crude fiber (\%) & 30.94 \\
Ether extract (\%) & 5.66 \\
Total Digestible Nutrient (\%) & 71.96
\end{tabular}

Badarina et al. (2013)

condition may be attributed to nematodes infection with relation to nutrient intake and the nutrient utilization by animals (Pathak and Tiwari, 2012). On T0 (no chemical anthelmintic treatment and no supplementation of fermented coffee husk), the dry matter intake and daily gain was the lowest. The mean of faecal egg count (FECs) is presented in Tabel 4. At the beginning of this research, all animals were infected by the nematodes. The level of nematodes infection were moderate because the faecal egg counts were range 500-5000 eggs/g faeces (Soulsby, 1982). After treatment, the animals in T1 (with fermented coffee husk supplementation) and T2 (with chemical anthelmintic treatment) were in good health. There were no nematodes infection in $\mathrm{T} 1$ and $\mathrm{T} 2$ shown with the faecal egg counts were zero while the animals in $\mathrm{T} 0$ were still infected.

The performance of the goats in this research were not optimally yet, this could be due to most of the nutrients were allocated to improve the immunity. Cunningham-Rundles (2006) reported that nutrition was the main factor to improve the immnunity. During a disease challange, nutrient are shunted away from growth and are used by specific cells to mount an immune system (Ingvartsen and Moyes, 2013). Pathak et al. (2013) stated that GIN infection caused extensive abomasal tissue damage, haemorraghe and protein losses and redirected protein synthesis away from growth.

Though there was no statistically significant difference between treatment groups, the weigth gain on $\mathrm{T} 1$ and $\mathrm{T} 2$ were higher than $\mathrm{T} 0$. This indicates that the health of animals on $\mathrm{T} 1$ and $\mathrm{T} 2$ are better than T0 group. Roche and Berry (2006) stated that there was assosiation between body condition and health.

\section{Blood Profile}

Blood parameter is one of the methods used to assess nutritional and health status of animals. Changes in haematological characteristics could be used as a measure of the nutritional or physiological status of the animal (Ndlovu et al. 2007; Ekenyem and Madubuike, 2007). Feeding fermented coffee husk (T1) and T2 (chemical anthelmintic treatment) in GIN infected goat improved $\mathrm{Hb}$ and $\mathrm{RBC}$ value $(\mathrm{P}<0.05)$ as shown in Table 3. The reduced $\mathrm{Hb}$ values in $\mathrm{T} 0$ possibly related to nematode infection. The reduced $\mathrm{Hb}$ in infected animal may be attributed to the bleeding of abomasum and intestines due to injuries caused by the parasites (Rowe et al., 1988). Fermented coffee husk supplementation to infected goat prevented a marked decreased in $\mathrm{Hb}$. The improving the health of animal in $\mathrm{T} 1$ and $\mathrm{T} 2$ possibly related to the effect of fermented coffee husk and chemical anthelmintic as control of GINs.

The decreasing and increasing of PCV and eosinophil counts had been known as the indicator of parasite infection. No statistically significant differences were observed in PCV and eosinopil counts. The PCV counts decreased on T0. PCV is the most accurate means of determining red blood cell volume and can be used to deduce total blood volume and haemoglobin levels. The decreasing of PCV counts meaned that there had been decreasing of red blood cells counts and decreasing of $\mathrm{Hb}$ concentration in blood (Widjajanti et al., 2002). Eosinophil counts on T0 group was the highest. This condition possibly related to the immune responsiveness of animals to GIN infection. The eosinophil counts associated with the level of parasite infection. Tuasikal and Suhardono (2006) reported that the eosinophil counts were higher on goats with gastro intestinal nematodes infection.

The percentage of eosinophil count change were lower in T0. This condition indicated that the immune system on T0 still fought against the 
Table 3. The Weight Gain and Dry Matter Intake in Feeding Trial

\begin{tabular}{lccr}
\hline \multirow{2}{*}{\multicolumn{1}{c}{ Variables }} & \multicolumn{3}{c}{ Diets } \\
\cline { 2 - 4 } & \multicolumn{1}{c}{ T0 } & \multicolumn{1}{c}{ T1 } \\
\hline Avarage weight gain, g/day/head & $33.571 \pm 24.94$ & $44.29 \pm 19.69$ & $62.86 \pm 49.14$ \\
Dry matter intake, g/day/head & $691.31 \pm 128.23$ & $792.01 \pm 128.79$ & $801.34 \pm 159.26$ \\
\hline
\end{tabular}

Tabel 4. Blood Profile of the Goats in Feeding Trial

\begin{tabular}{|c|c|c|c|}
\hline \multirow{2}{*}{ Items } & \multicolumn{3}{|c|}{ Treatment } \\
\hline & T0 & $\mathrm{T} 1$ & $\mathrm{~T} 2$ \\
\hline \multicolumn{4}{|l|}{ Haemoglobin, g/dL } \\
\hline - Baseline & $8.15 \pm 1.55$ & $8.32 \pm 1.10$ & $7.23 \pm 0.86$ \\
\hline - Post-analytical & $5.55 \pm 1.90^{\mathrm{a}}$ & $8.62 \pm 1.50^{\mathrm{b}}$ & $9.20 \pm 2.46^{\mathrm{b}}$ \\
\hline - \% of change & -31.92 & +3.61 & +27.25 \\
\hline \multicolumn{4}{|c|}{ Packed Cell Volume (PCV), \% } \\
\hline - Baseline & $24.00 \pm 4.58$ & $23.50 \pm 4.46$ & $21.50 \pm 2.29$ \\
\hline - Post-analytical & $21.00 \pm 6.59$ & $25.17 \pm 4.37$ & $27.50 \pm 7.43$ \\
\hline - $\%$ of change & -12.5 & +7.11 & +27.91 \\
\hline \multicolumn{4}{|c|}{ Red Blood Cells (RBC), 106/ $\mathrm{mm}^{3}$} \\
\hline - Baseline & $11.28 \pm 1.72$ & $11.16 \pm 1.48$ & $9.44 \pm 1.04$ \\
\hline - Post-analytical & $7.40 \pm 2.52^{\mathrm{a}}$ & $11.40 \pm 2.04^{\mathrm{b}}$ & $12.20 \pm 3.24^{\mathrm{b}}$ \\
\hline - \% of change & -34.40 & +2.15 & +29.24 \\
\hline \multicolumn{4}{|l|}{ Eosinophil count, \% } \\
\hline - Baseline & $2.75 \pm 0.83$ & $1.50 \pm 0.40$ & $1.50 \pm 0.82$ \\
\hline - Post-analytical & $2.50 \pm 1.12$ & $1.33 \pm 0.75$ & $1.25 \pm 0.83$ \\
\hline - $\%$ of change & -9.09 & -11.33 & -16.66 \\
\hline \multicolumn{4}{|c|}{ Faecal Egg Count (FEC), egg/g faeces } \\
\hline - Baseline & 681.25 & 687.5 & 531.25 \\
\hline - Post-analytical & 37.5 & 0 & 0 \\
\hline
\end{tabular}

Different superscripts in same row indicate significantly different $(\mathrm{P}<0.05)$

nematodes infection. Estuningsih et al. (2002) stated that eosinophil cells are one of the immune cells to protect from parasite infection.

\section{CONCLUSION}

The result of the current study confirmed the potency of fermented coffee husk as natural anthelmintic feed supplement in ruminant diets.
Fermented coffee husk could be used as anthelmintic feed supplement with the improvement of $\mathrm{Hb}$ value, $\mathrm{RBC}$ counts, egg counts and daily weight gain of goats.

\section{ACKNOWLEDGMENTS}

This work was supported by research fund from Directorate General of Higher Education, 
Education Ministry through HIBAH STRATEGIS NASIONAL with research agreement number 344/UN30.15/LT/2015 on March $10^{\text {th }} 2015$ batch 1. Thank you very much to our students, Friend Aritonang and Dodi Sismanto for helping on farm. Also, special appreciation to drh. Jananta from The Veterinary Health Laboratorium Bengkulu Province for animal health discussion.

\section{REFERENCES}

Badarina, I. 2013. The Use of Coffee Husk as Bioconversion Product from Pleurotus ostreatus to Improve The Healthy and The Perform of Lactating Dairy Goat. Dissertation. Bogor Agricultural University, Bogor,

Badarina, I., D. Evvyernie, T. Toharmat, E.N. Herliyana and L.K. Darusman. 2014. The use of coffee husk fermented with Pleurotus ostreatus as feed supplement improved haematological properties in Etawah dairy goat suffered from subclinical mastitis. The Proceeding of The $2^{\text {nd }}$ Asian-Australasian Dairy Goat Conference. Faculty of Animal Science, Bogor Agricultural University, Bogor, Indonesia. April 25-27 ${ }^{\text {th }}, 2014$, Pp: $155-157$

Chen, J. and R. Seviour. 2007. Medicinal importance of fungal $\beta-(1-3)$, (1-6)glucans. Mycological Res. III:635-652

Cunningham-Rundles, S. 2006. Evaluation of the effects of nutrients on immune function. Frontiers In Nutritional Science No.1. Nutrition and Immune Function. Edited by Calder, P.C., C.J. Field and H.S. Gill. CAB International. UK.

Ekenyem, B.V and F.N. Madubuike. 2007. Haematology and serum biochemistry of grower pigs fed varying of Ipomoea asarifolia leaf meal. Pakistan J. Nutrition. 6: 603-606.

Estuningsih, S. E., S. Widjajanti, S. Partoutomo, T. Spithill, H. Raadsma and D. Piedrafita. 2002. In vitro studies: The role of immunological cells in Indonesian thin tail sheep in the killing of the liver fluke, Fasciola gigantica. Indonesian J. Anim. Vet. Sci. 7(2):124-129.

Herliyana, E. N., D. Nandika, Achmad, L. I. Sudirman and A. B. Witarto. 2008. Biodegradation of sengon-wood sawdust substrate by Pleurotus group fungi from
Bogor. Journal Trop. Wood Sci. Technol. 6:75-84.

Ingvartsen, K.L. and K. Moyes. 2013. Nutrition, immune function and health of dairy cattle. Animal. 7:112-122.

Jain, N.C. 1993. Essential in Veterinary Hematology. Lea and Febiger. Philadelpia. USA.

Kearl, L. C. 1982. Nutrient requirements of ruminants in developing countries. International Feed Stuffs Institute, Utah Agricultural Experimental Station. Utah State University, Logan.

MAFF (Ministry of Agriculture Fisheries and Food). 1986. Manual of Veterinary Parasitology Laboratory Techniques. $3^{\text {rd }}$ ed. Ministry of Agriculture Fisheries and FoodUK. HerMajesty's Stationary Office London.

Matanovic, K., K. Serevin, F. Martinkovic, M. Simpraga, Z. Janicki and J. Barisic. 2007. Haematological and biochemical changes in organically farmed sheep naturally infected with Fasciola hepatica. Parasitol. Res. 101:1657-1661.

Ndlovu, T, M. Chimonyo, A. I. Okoh, V. Muchenje, K. Dzama and J.G. Raats. 2007. Assessing the nutritional status of beef cattle: current practices and future prospects. Review. African Journal of Biotechnology. 6 (24): 2727-2734.

Patel, Y., R. Naraian and V.K. Singh. 2012. Medicinal properties of Pleurotus species (Oyster mushroom): A review. World J. Fungal and Plant Biol. 3(1):01-12.

Pathak, A. K. and S. Pal. 2008. Seasonal prevalence of gastrointestinal parasites in goats from durg district of Chhattisgarh. Vet. World. 1:136-137.

Pathak, A.K. and S.P. Tiwari. 2012. Influence of Haemonchus infection on nutrient intake and its utilization in kids fed different level of nutrition. Indian J. Anim. Nutr. $29: 52-57$

Pathak, A.K., N. Dutta, P. S. Banerjee, A. K. Pattanaik and K. Sharma. 2013. Influence of dietary supplementation of condensed tannins through leaf meal mixture on intake, nutrient utilization and performance of Haemonchus contortus infected sheep. Asian Australas. J. Anim. Sci. 26(10): 14461458.

Roche, J. R and D. P. Berry. 2006. Peripaturient climatic, animal and management factors influencing the incidence of milk fever in 
grazing systems. J. Dairy Sci. 89:27752783.

Rowe, J. B., J. V. Nolan, G. de Chaneet, E. Teleni, and P. H. Holmes. 1988. The effect of Haemonchosis and blood loss into the abomasum on digestion in sheep. Br. J. Nutr. 59:125-139.

Sissouma, S., M. Ouattara, M.W. Koné, H.E. Menan, A. Adjou and L. Ouattara. 2011. Synthesis and in vitro nematicidal activity of new chalcones vectorised byimidazopyridine. Research paper. African J. Pharmacy and Pharmacol. 5(18):20862093.

Soulsby, E.J.L. 1982. Helminths, Protozoa and Antropods of Domesticated Animal. $7^{\text {th }}$ Edition. Bailliere Tindall, London.

Steel, R.G.D. and J.H. Torrie. 2003. Principles and Procedures of Statistics. $2^{\text {nd }}$. Mc. GrawHill Book Co. Inc., New- York.

Suharti, S., K.G. Wiryawan, R. Tiuria, Y. Ridwan, S. Fitriana and N. Sumarni. 2010. Eflectiveness of Jatropha curcass Linn leaves as an anthelmintic for Ascaridia galli and its eflect on native chicken performance. Med. Pet. 33(2):108-114

Tuasikal, B.J. and Suhardono. 2006. The effect on infection of irradiated Fasciola gigantica (liver flukes) on goats (Capra hircus Linn) blood values. Indonesian JITV. 11(4):317323.

Widjajanti, S., S. E. Estuningsih, S. Partoutomo, H.W. Raadsma, T.W.Spithill and D. Piedrafita. 2002. The responses of eosinophil and packed cell volume (PCV) on sheep infected with Fasciola gigantica. Indonesian JITV. 7(3):200-206.

Wolstenholme, A.J, I. Fairweather, R. Prichard, G. von Samson- Himmelstjerna and N.C. Sangster. 2004. Drug resistance in veterinary helminthes. Trends in Parasitology. 20:469-476.

Wong, K.H., C.K.M. Lai and P.C.K. Cheung. 2011. Immunomodulatory activities of mushroom sclerotial polysaccharides. Food Hydrocolloids. 25:150-158.

Zafar, I., A.M. Kamran and N.K. Muhammad. 2004. Anthelmintic effects of condensed tannins. Int. J. Agric. Biol. 4:438-40. 